\title{
The Colonial Hotel: spacing violence at the Grande Hotel, Beira, Mozambique
}

EPD: Society and Space 2019, Vol. 37(2) 276-293

(C) The Author(s) 2018

Article reuse guidelines: sagepub.com/journals-permissions DOI: $10.1177 / 0263775818800719$ journals.sagepub.com/home/epd

@SAGE

\section{João Sarmento}

Geography Department \& Communication and Society Research

Centre, University of Minho

Campus de Azurém, 4800-058 Guimarães, Portugal

\section{Denis Linehan}

School of Geography and Archaeology, University College Cork, Western Road, Cork, Ireland

\begin{abstract}
In spite of its dereliction, the Grande Hotel in Beira, Mozambique, has emerged as an iconic African building. The dissonant meanings of this site, offer multiple opportunities to investigate the intersection of space and colonialism. We focus upon the cultural and political topologies of the hotel, and of colonial hotels generally, and make the proposition that they were a particular kind of violent colonial institution. By converging a relational reading of both violence and architecture, we reconstruct through the excavation of archival and related materials, the processes present in the histories of the hotel and city at large, to unmask how they acted as spaces of slow violence. White settler's activities and rationales were underpinned by deliberative strategies of unknowing, forgetting, disavowal which together formed a kind of cultural agnosia that insulated them from the foundational violence that supported the colonial condition. We use a dispersed concept of violence, understood as a tactical and mutable process, which moves between physical, symbolic, embodied and performative domains. We address these domains in the paper through an analysis of the ways the city of Beira was planned, its architecture shaped and represented, and in the recreational and social performances within the hotel.
\end{abstract}

\section{Keywords}

Settler Colonialism, Slow Violence, Grande Hotel, Mozambique, Beira

\footnotetext{
Corresponding author:

João Sarmento, Geography Department \& Communication and Society Research Centre, University of Minho, Campus de Azurém, 4800-058 Guimarães, Portugal.

Email: j.sarmento@geografia.uminho.pt
} 


\section{Introduction}

Over the last decade, the Grande Hotel in Beira, Mozambique has emerged as an iconic African building. This structure, currently home to several thousand inhabitants, is in ruins. In 2009, the South African photographer Guy Tillim featured the derelict hotel in his exhibition Avenue Patrice Lumumba. He pictured the heroic qualities of the dilapidated building, which once claimed to be the most luxurious hotel south of the Sahara, juxtaposing a mausoleum of colonialism with a vibrant but hazardous urban habitat. The fusion of lost dreams and precarious livelihoods in one site makes this architecture intensely emblematic. Part of Tillim's aesthetic allowed the hotel's aura to stand both for itself and for other places. Stripped of its adornments, such as marble walls and parquet flooring, his depiction of the ghostly shell of the hotel - lobbies, grand staircases, reception rooms - accentuate the poverty of the inhabitants living in the spaces of faded grandeur. These qualities have encouraged several filmmakers (Saint-Maurice, 2007; Stoops, 2010) to explore the rise and fall of the Portuguese Empire at this site, and its post-independence after-life. There is however, an ambiguous quality to many of these narratives. Coursing through the stories and images of this building - notably those circulated on social media sites - are waves of nostalgia, notably from Portuguese and Rhodesian settlers who recall their youth the city in the 1950 s as 'the best of times'.

In this paper, we concentrate on the birth of this hotel and contend that the history of this place is a history of violence. To critically interrogate its significance and contribute more broadly to deepening our understanding of the critical typology of hotels in colonialism, we build upon recent work on the geographies of violence and its intercessions with the urban environment (Craggs, 2012; Goh, 2010; Peleggi, 2005, 2012). In particular we engage work that operates a relational conception of violence that is attendant to its multiple effects and forms. Whether examined in terms of the foundational violence and racist compact of American suburbia (Pulido, 2000), the entanglements of urban planning and war (Graham, 2010), or the damaging intersessions between violence and architecture (Kenzari, 2011; Tschumi, 1996), this scholarship makes a compelling argument about how violence can be produced and experienced across and in-between epistemic, embodied, physical and symbolic domains and over heterogeneous zonalities and temporalities. Influential in shaping our approach is Rob Nixon's (2011) concept of 'slow violence'. This kind of violence he characterizes as a mutable, often invisible, frequently attritional, and accumulative process, capable of working across and in-between physical, symbolic, embodied and performative domains and temporalities. Inspired by this approach, we argue that the processes involved in the site of the hotel can be unmasked by recognizing that violence is more than an abrupt harmful event, but is also a social and spatial process, capable at the very least of being expressed more slowly over time and space or enacted concealed or disguised in apparently benign practices - such as tourism or hospitality (Fregonese and Ramadan, 2015; Minca and Ong 2016; Bufacchi, 2017; Peleggi, 2005, 2012).

Though Nixon's focus has been upon environmental issues, his insights have clear utility into thinking though the violence inherent to wider colonial and post-colonial geographies (de Leeuw, 2016). These concerns are echoed in the rich literature which has traced the multiple forms of violence in the colonial city (Alsayyad, 1992; Anderson, 2015; Bigon, 2013; King, 2007; Kusno, 2000; Legg, 2007) and as well as research that has identified the violence embedded in colonial tourism (Hom, 2012). Moreover given its basis in relational thinking, these conceptions of violence find a welcome counterpart across work in human geography shaped by comparable flat ontologies (Marston, Jones and Woodward, 2005; Springer, 2014). In this paper, we articulate these possibilities further by drawing upon 
work on the border between geography and architectural studies, which investigates the relational and performative qualities of buildings and the uses they are put towards (Lees, 2001; Kraftl, Adey 2008; Leatherbarrow, 2009; Vasudevan, 2011). As Lorne (2017: 269) suggests, these accounts have '...de-centred the agency of architects in the production of architectural space' and underline the possibilities of a critical geography of architecture more attendant to practice and the non-representational'.

At stake here for us is our realisation that bringing these relational approaches to violence and the built environment together makes a difference to how one conducts research into the colonial city. This vital conjunction offers critical insights into institutions and practices that may be disregarded otherwise. Among other forms, in colonial Mozambique, exploitation was expressed through enforcing the cultivation of cash crops, through the establishment of sugar, copra, and sisal plantations, notably the Sena Sugar Estates, that were farmed by forced labour (see Newitt, 1995; Penvenne, 1995), and through recruitment of mining labour force to neighbouring countries. In light of the manifest racism and brutality experienced in these sites, our interest in the short life of a luxury hotel might appear superfluous. But like the mining complex or the plantation, hotels were significant spaces where the shaping of social relations of the colony took place. Across the global history of colonial modernity, hotels operated as gateways for white settlers' entry to colonial life, and signified the radical commodification of indigenous lands for tourism or economic development. In contrast to the conclusion devised by Siegfried Kracauer (1995), who saw in the hotel a space of anomie, we propose that for white settlers, the colonial hotel was an oasis, a sanctuary and a living archive of home, a source of security and means to constitute social relationships, rather than dissipate them. As a 'home away from home', the colonial hotel promoted various emotional attachments, and was an active agent in the construction of ways of knowing, being and doing in the colony. The hotel was a key element in the topology of the colony, a node that provided a particular visibility to guests - to see and to be seen through various encounters and performances. Of particular interest to us, is how within the enclave of the hotel, the violent foundation of colonialism was constructively elided, as a means to restore emotionally and psychologically the beneficiaries of the colonial settlement, bolster their feelings of white privilege and shore up their identities as modern.

In making these observations, we acknowledge the research on the intersection of settler space and settler identity, which has addressed how spatial practices and sites were manipulated both discursively and materially to support the colonial project (Lester, 1998; Foster, 2008). In this sense, whilst we argue that this particular hotel offers intense insights into colonial urbanism, we are not proposing that the Grand Hotel da Beira is an exceptional site. Nor do we claim that locating violence in the colonixal hotel is necessarily a unique insight. As observed in I. N. C. Aniebo's novel The Anonymity of Sacrifice (1974) and Bernard Dadié's Climbié (1984) the hotel for indigenous populations was frequently portrayed as an exploitative site, a locus of white power and sexual exploitation. We do suggest however that hotels were part of a whole archipelago of settler institutions: such as clubs, safaris, race-courses and so on, which were crucial to the production of settler identity. Many of these sites, typologies and practices, offered what McDermott-Hughes (2010: 55) in his study of conservation in Rhodesia has termed 'social escape'. These white settler's activities and rationales were underpinned by deliberative strategies of unknowing, forgetting, and disavowal which together formed a kind of cultural agnosia that insulated the settler from the foundational violence that underpinned the colonial condition. (Henderson, 2017). Surrounded by luxury, resting in rooms and lobbies that offered a facsimile of Europe, or Orientalist and Tropicalist space, under the influence of colonial agnosia guests were 
enabled to lose sight of the meaning and impact of the performances and structures that supported colonialism (Byrd, n.d.; Arndt, 2016). In this paper we illustrate how these conditions were lodged in the colonial planning of Beira, in the architecture of the Grande Hotel, in its nostalgic interior design, and in the frivolous events like fashion shows and beauty contests that took place there, as well as being more broadly expressed in the colonial city constructed around it.

\section{Organisation of the Paper}

Through the analysis of archival materials sourced in Mozambique and Portugal, we reconstruct the array of violent processes that were present in the construction and functioning of the hotel and city at large. During 2015 archives related to the developers of the hotel, the Companhia de Moçambique were located in the National Library of Mozambique, Maputo, the National Archive of Torre do Tombo and the Historical Overseas Archive in Lisbon. The newspapers Notícias da Beira (NB) and Diário da Beira (DB) were mostly accessed in Beira. While acknowledging that these newspapers aimed at portraying a positive and progressive view of the colony, and were all tightly controlled by the government, they provide rich details of life in Beira. The newspaper Diário de Moçambique was also used. Established in 1951 by the Bishop of Beira, a clergy who strongly voiced his opposition against violence and colonial oppression, it escaped the claws of censorship up to 1964, when it was first suspended. Details of social life in the city are scarce.

In the first section of the paper, we focus upon the violence of occupation, its relationship to tourism and modernism and its position in the colonial expansions undertaken by the Estado Novo, the authoritarian regime that controlled Portugal from 1933 until the so called Carnation Revolution in 1974. In this analysis we refigure the long-standing interest in the relationship between dispossession and the colonial urban landscape as a form of slow violence.

Following on, we focus upon the construction of the hotel itself. We argue that through a reading of the minutiae of the project we can understand the elaboration of this settler site as a space both of identity formation and forgetting. This analysis involves an examination of the materialities of the building, through close examination of official letters, drawing out from the banalities of minutes of meetings of the Companhia de Moçambique and the reactions of the local media to the process of constructing a settler space. Here we underline - as has been the case with investigations in modernism in the tropics globally - that there was an inherent violence at work in this colonial architecture, whose legacies in the contemporary African city, continue to symbolise the histories of oppression (Amutabi, 2012; Mhango, 2015). These concerns we take up more fully in the final sections of the paper, when we turn to an analysis of a range of performances that took place at the hotel. We highlight these as dissociative rituals, and unmask their roots in a racist social formation. In the concluding section, we draw an analysis that illustrates the inevitable interdependence of each of these violent processes, to offer critical insights into the role of hotels across the global modernity of colonialism and beyond.

\section{Slow Violence and Dream Topographies in Beira}

In what follows, we turn to the urban contexts of the Grande Hotel and recast the colonial urban developments in Beira as a form of slow violence. This reading will show that in addition to construction of spaces and architectures of colonial dispossession, these urban interventions helped generated what J.M. Coetzee (1988: 6) has referred to as the 'dream 
topography' of white settler society. As we have noted above, this imaginative infrastructure was central to the cultural agnosia that undergirded the comfort zones of the colonial settler. Many of our observations are foregrounded by the explorations of violence made in classic interventions about the colonial city, addressed by Césaire (1950) and Fanon (1963) - to the body, to place, to language, to culture and the economy. But through a focus upon what Jacobs, Cairns and Strebel (2012: 128) underline as the relationally of urban spaces as a '...diverse gathering of contingently formed associates and associations', we mobilize Nixon (2011) realisation of slow violence as incremental and accretive. This pattern we reveal in terms of the way the Portuguese steadily reshaped the city into its colonial form. In the syntax, form and symbolism found in both its town planning and architecture, order was inscribed into the city. These constructions we argue, were a form of slow violence, revealed in its boulevards, buildings and squares, and also in the performances, notably around leisure and tourism they occasioned. Hotels benefited from the context created by the racist architectural and urban planning deployed in the colonial city (Demissie, 2007; King, 2007; Legg, 2007).

Beira is a coastal city in the central region of Mozambique, and holds an important geopolitical location in southeast Africa, serving as one of its principle ports. In its origins and role in colonisation, it became a gathering point for colonial forces and occupation, an administrative centre and a major centre for white settler tourism. During the colonial/ liberation war (1964-1975), which mostly developed in the north and northeast of the country, Beira increasingly played an important role as a haven for Portuguese troops. Located at the head of the Pungwe and Buzi rivers, in the colonial period it was second only to Lourenço Marques (Maputo) and was key to a vast hinterland including the Zambezi valley, South and North Rhodesia (Zimbabwe and Zambia) and Nyasaland (Malawi), which by the 1920s was connected by two main railway lines. Copper from Northern Rhodesia, and a portion of the output from the Katanga region were exported from here. These connections meant Beira became a strategic city in the convergence of the Portuguese and the British empires.

From 1892 to 1942, this large territory - presently Manica and Sofala - was governed and exploited by the Companhia de Moçambique (CM), through a 50 year concession. In the late nineteenth century, with a marginal presence and control in the north and central territories of Mozambique, and with few resources, the government followed an already established practice in colonial settlement and political economy. The concession of large territories to internationally funded chartered companies to which complete monopoly to all economic resources were granted, allowed them to act as states within a state (see Neil-Tomlinson, 1987 for details). The promotion and shaping of exploitation and dispossession was set. With varied success CM sought to exploit the plantation agriculture and mineral deposits in the region and to create a profitable colonial economy. This company was also licenced by the Portuguese colonial office to coerce the indigenous people into forced labour. The result was, according to Anderson (1962: 83), extensive exploitation, and 'ultra-colonialism': 'Mass forced labour: de facto pass laws: omnipresent foreign capital: an incendiary white lumpenproletariat: a superstructure of magic: an economic and social machine turning in a void, driven by pure terror'.

This terror was consistently disguised in the rational plans made for the city, where the CM headquarters were located, which we can take as both an analogue and an instrument of the slow violence enacted through the management of the built environment under colonialism. Having acquired city status in 1907, in the decades that followed the CM sought to address its infrastructural deficits. Attracting investment was deemed critical, not least so the city would 'occupy its planned place in the colony' (CM, 1943, 2 April). In addition to its 
commercial and port related interests, from the 1920s onwards the city became the focus for tourism, being the best served seaside destination for white settlers in its hinterland. For Rhodesian holidaymakers, Beira was just a four hour drive from the border town Umtali (Mutare). Air-conditioned sleeper cars could transport visitors in luxury overnight by rail from Salisbury (Harare). The airport had international connections, and the airlines promoted the city as both a beach resort and safari in the Gorongosa National Park.

Increased tourism meant that several new hotels of international standard augmented what had been a town of boarding houses and family hotels. One new motel and campsite, Estoril, designed by Melo Sampaio could cater for up to 3,000 visitors. This investment reflected the general success of tourism in Mozambique which saw a string of new hotel developments on its coastline during this period. This became the city remembered by Graham Lord (1990: 19) as the place his father '. . .played cricket and croquet, and billiards under huge lazy fans in the Beira Club, and left visiting cards, and watched with full hearts the flying-boats from 'Home' landing on the Pungwe River, and waltzed until dawn at the old Savoy Hotel to Ruby Maclean's band.' A comparative level of obliviousness to the foundational violence of colonialism was reflected in memories of another visitor who recalled his impression of holidays in the city as '...the broom swish of coconut palms, the sweet taste of sugar coated roasted chestnuts... the Tennessee rock blues from a hop at the Chinese community centre, the impossible friendly smile of a girl in an Oriental talmi gold bazaar' (Dean, 1979: 18). It should be recalled however, that holidays take on a different meaning when conducted in colonial contexts. When holidays were taken it was a means to exercise white identities, forge myths, all funded through the benefits of the colonial economy - profits from land and ore acquired through conquest, or from crops harvested in plantations by indigenous labour.

This process of development and erasure accelerated around the time the Grande Hotel was built in the early 1950s, driven by an expansionary colonial policy devised by the Estado Novo, and better economic growth, notably following the establishment of the Central African Federation (1953-1963). Urban development was managed through Lisbon and encouraged by measures to promote real estate, such as the lowering of interest rates. Arrivals from Portugal rose from 1,900 in 1937 to 10,000 in 1959, and dispossession and violence was blatant, as Isaacman and Isaacman (1983: 43) argue: 'By the 1960s the 3,000 European planters and farmers controlled more land than 1.5 million African peasants'. Growth reflected the confidence in the future of the colony, paradoxically in the face of the decolonisation progressively gaining momentum elsewhere and the increasingly unstable geo-political situation in the region, notably in Rhodesia.

Set against our approach which aims at unmasking these histories of slow violence embedded in these urban developments, both the city's planning and architecture can be identified as a conscious effort to invent a city that would offer prestige and comfort to the colonists (Andrade, 1932). According to Milheiro (2012), the Estado Novo regime enabled the Gabinete de Urbanização Colonial (Colonial Office of Urbanisation) to produce and regulate schemes to modernize the built landscape in the colonial territories, using technology of urban planning and the standardization of public buildings as a key way to represent Portuguese authority in its colonies. This organization helped marshal an official style for the tropics, characterized by traditionalism and a muted monumental classicism. Beira's urban development, can be located as part of the broad 'garden cities' movement in Africa (Bigon, 2013), and an attempt to prove that vernacular architectural elements of southern Portugal could seed a tropical architecture (Milheiro, 2012; Silva, 2016). The spatial imprimatur of this colonial disposition was certainly in place in the urban plan for the city created by the architects José Porto and Joaquim Alegre in 1946. 
If space is a resource through which power is exercised, these colonial designs on Beira reveal what Mudimbe (1988: 59) names as the '...formal and elaborate ceremony of appropriation of a terra nullius'. In what appears at first glance, as a series of benign interventions, they envisioned an orderly city, zoned according to broad commercial, industrial, tourist and residential sectors, with a layout that drew upon classical models, with boulevards, squares and monuments, underscored by functional and ethnical divisions between Europeans, Asians, and Africans. But not only did this plan frame the spatial organisation of the city within a larger process of dispossession but in its commitment to prestige and beauty, occupied the city with a wholly European imaginary by shaping parts of Beira into the likeness of a European resort town. This plan is especially interesting, as its principal author, José Porto, also designed the Grande Hotel, enveloping both a general plan for the city and a specific design for the hotel in the conservative stable imaginaries of continuity and state power promoted in Lisbon, a move that would locate these new colonial spaces as show-cases for the regime.

Especially interesting in terms of the intersections between colonialism and slow violence was the work of a new generation of Portuguese architects who converged on Beira (Fernandes, 2002; Milheiro, 2012). The production of the colonial city through the lens of modernist and tropical science was a widespread aspect of the development of colonial cities in Africa, and Beira certainly was shaped by these developments. The structures built by this group included Cine-Theatre São Jorge (1954), the Tourism Pavilion (1954), the church of Manga (1955), the Autómovel and Touring Clube de Moçambique (1957), the Embaixador Hotel (1958), the Motel Estoril (1959), the exhibition building of Casa dos Bicos (1962), and the railway station (1966).

Of particular interest is the way that several buildings were richly decorated with tiles, murals or mosaics, depicting Africanist motifs. These syncretic flourishes mirrored the discursive emphasis of the propaganda cultivated during the Estado Novo regime, whose ideology of Lusotropicalismo argued that Portuguese were uniquely situated and better suited to colonize than any other colonizers. Amongst some critics, these ideals remain in currency. Tostões (2013:67) characterizes these architects as 'good missionaries' interested in 'the support of colonial welfare' (...) 'in the name of human progress and justice'. These benign readings depict a kind of liberated modern tropical architecture, freed from the conservative straitjacket enacted by the authoritarian Estado Novo. However, these expressions of tropical modernism arrived at a time when political resistance in the African colonies was growing. In 1953 uprisings were reported in Mambone, just south of Beira (Isaacman and Isaacman, 1983), and in 1960, the Mueda massacre, in the north, triggered resistance in the region (Alexandre, 2017). Strongly influenced also by developments in neighbouring Rhodesias and Nyasaland, a military build-up was put in place. Even if the nationalist campaigns were largely confined to the extreme north and to parts of the Lake Nyasa up to the late 1960s, a company of 200 paratroopers was stationed in Beira, and 'all Portuguese were invited to form self-defense groups' (Alexandre, 2017: 517).

Far from being benign developments, together with the town planning, colonial buildings inscribed power and demonstrated the tangled interdependence of the languages of modernism and colonialism at this time (Anderson, 2015). They acted as the material support for the strong racial division in place: indigenous peoples were forbidden to use cafés, cinemas and other social spaces and up to 1960 a curfew was in place (Alexandre, 2017).

\section{The Birth of the Grande Hotel}

At the beginning of this paper we proposed that the production of the colonial hotel, where white colonial settlers could dissimulate and dissipate the effects of exploitation was 
elemental to the apparatus of violence in the colonial project. The apparently non-violent characteristics of these spaces, the practices involved, and to some extent their superficiality and frivolousness has meant that the violence they embodied has been overlooked in the context of the colonial city. However once attended to, and recovered from the archive, the characteristics and activities within and of these spaces can be unmasked. Leatherbarrow's (2009) proposition that we must escape the 'sovereignty of buildings' and address their wider contexts, relationships and performances, has animated our search for violence in the archives of the hotel. When contextualised within the types of physical and political violence that they were enabled by, and in turn enabled, they can be reframed. In fact, the Grande Hotel was in the vanguard on the developments described above, anticipating in its scale, exuberant form and impact, the intentions of the colonial ambition that Portugal had for the city.

Having drafted a plan for the city, José Porto designed a grandiose, curvilinear building with arcades and lavish balconies open to the Indian Ocean. The choice of this style of hotel is symptomatic of an expansive state. Since the nineteenth century glamorous 'grand hotels' became a prestigious addition to cities and were often linked to boosterist urban strategies (Denby, 1998; Katz, 1999; McNeill, 2008). In the case of the Grand Hotel, the preoccupation with luxury and status was driven from Lisbon. Sidaway and Power (2005: 538) argue, as a means to work through their own imperial anxieties colonial policy makers in Lisbon, conscious of their economic and political limitations, often sought opportunities to 'to play out its unique and heroic destiny on the world stage' (see also Linehan and Sarmento, 2011).

The initial idea had emerged in 1942 in a proposal authored by Lacerda Marques - an architect with a busy practice in the colony - when the Companhia de Moçambique requested permission to build a hotel with 100 rooms (CM, 1942, 27 February). The Ministry of the Colonies endorsed the construction but recommended expanding the project to include a restaurant and dining areas (CM, 1942, 17 December). However, the early development of the hotel was strained, as various concessions on loans and the size and quality of the building were worked out between colony and metropole. In the banal and formulaic letters to the Ministry of the Colonies we find many insights into the commercial concerns of colonial capitalism, such as their complaint that the construction of hotels in Lourenço Marques was happening under more advantageous financial conditions (CM, 1943, 22 February). The CM asked to modify the 1943 construction starting date, as there were problems with the municipal public water and electricity supply.

With their eye on their modernisation agenda, they argued that it would be useful to have an urban plan for the area where the hotel was to be located (CM, 1943, 19 March). One of the immediate results of these negotiations was that the Ministry required the Hotel to have at least an auditorium that could cater for 400 people, four large luxury apartments, a dining room for 300 people, a grand ballroom, a library, a reading room, 'rooms for ladies', reserved dining rooms, a barber and a hairdresser: 'in short, as long as it is a Grand Hotel, with modern standards' (CM, 1943, 25 March). This expansion of the building's programme is key, as it roots the enlargement of the hotel in the ministry in Lisbon. Colonial administrators clearly envisioned the hotel beyond the remit than simply accommodation. Their aim was to create a site which could signal clear confidence in the sustainability of the colony, and produce a settler space that would alleviate and assuage the psychological costs of prosecuting colonialism.

Construction eventually commenced in August 1949 (DM, 1955, 16 July: 1). At a cost of 75 million escudos (2,6 million dollars), seven times more the estimate put forward 12 years before, this was the largest private development to occur in Beira for decades. In total 450 European and 2000 indigenous worked there at a total cost of 18 million escudos 
(DM, 1955, 16 July: 8-9). There were high expectations amongst the white population in the city regarding its inauguration. In March 1955, the local newspaper Notícias da Beira published a story about the lighting test of the building: '(...) the effect is stunning. The intensity of light, appropriately distributed, the beautiful and spectacular chandeliers and various lightening systems create wonderful results' (Notícias da Beira, 1955, 17 March: 5). The opening ceremony on 16 July 1955 was extravagant and widely reported. The CM administrators travelled from Lisbon to host the ceremony. Prestigious figures in the colonial administration attended, including the General-Governor of Mozambique. Following a lavish banquet and a ball for 400 people, the celebrations ran on until 4am. Ritmo, the local orchestra, enlivened the event and their performance was broadcasted by the Radio Club of Mozambique.

Painted in beige with white accents at the façade of the main entrance, the inaugural photographs of the hotel portray an immaculate building - which was in many ways a site of purification, a symbol of the progress and wealth of the colony (Figure 1). A central opulent block and a grand Art-Deco entrance was complemented with four other blocks, all connected via wide glass-enclosed corridors. It was the largest concrete building in all the empire (Saint-Maurice, 2007), despite having 130 rooms only, a drawback, which in time would be regretted. The hotel occupied an entire block in Ponta Gêa, the most prestigious and Europeanised neighbourhood of Beira. There were three state-of-the-art Schindler elevators, plus 4 food elevators, an elaborate telephone network, three kitchens capable of serving 500 people daily and a laundry able to wash 1000-4000 kg per week (DM, 1955, 16 July: 12). The building's $20,000 \mathrm{~m}^{2}$ included a nightclub, shops, various saloons and dining rooms, all sumptuously decorated with natural furnishings, woollen carpets, leather armchairs, two pianos, billiard tables, china and chandeliers imported from Europe. In fact, the archive reveals an inventory of 4227 objects worth over 7 million

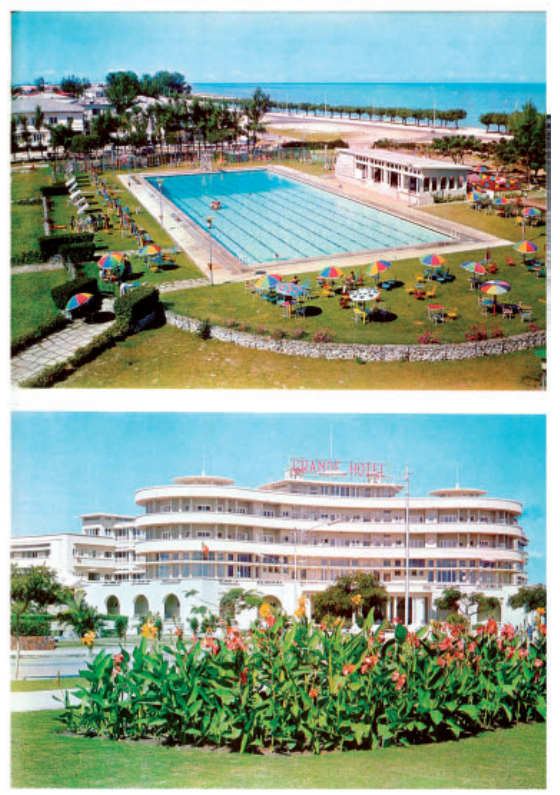

Figure I The Grande Hotel, Beira, Mozambique, 1960s.

Source: Frederic P. Marjay (1963) Mozambique. Bertrand: Lisbon. p.35. 
escudos (CM, 1959). These spaces of comfort were complemented with an Olympic size swimming pool with an outdoor bar, plus generous gardens, which gathered the city elites in a refreshing and safe environment. On this basis the hotel claimed to be '...one of the most sumptuous hotels in the world' (DM, 1955, 16 July: 12).

It may seems counterintuitive to claim these things as elemental to the prosecution of slow violence, but these luxuries, technologies and services created what Peleggi (2005) terms 'temporary replacement', a condition that offered guests an experience of being in the familiar time and space of Europe. In state-sponsored systems, the exercise of violence is maintained not only by its legitimation, but also by suppressing its memory, keeping it at a distance, and securing certain comfort zones as a means to restore the perpetrator (Peleggi, 2012).

\section{Pleasure and Violence}

Based upon our work in the archive of this hotel, we argue that the practices enabled at the hotel supported a similar kind of moral disjuncture which Zigmund Baumann (1989) identified as essential to the prosecution of trauma. Whilst the contexts differ, just as Enloe (2000) has established how integral the provision of 'Rest and Recreation' for American troops was to their role in the Korean and Vietnam war, we see in the hotel how the management and supply of pleasure was essential to the prosecution of the violent framework of colonialism. Once again however, like the modernist tropical architecture or apparently benign urban planning, the domain is disguised and camouflaged, characterised as it is by a trail of parties, dinners, fashion shows, concerts, swimming and sunbathing. Following its opening, the hotel became a focal point in the city and a fashionable destination for those travelling for business or pleasure. A night-club or 'Boite de Nuit' was opened (DM, 1955, 30 July: 9). This nightclub was particularly lively, with 'music, dancing, good food and all sorts of wines' (Notícias da Beira, 1956, 7 January: 1-2). Various music shows took place in the hotel, with either local musicians, or renowned artists from Lisbon booked on colonial tours.

These performances mirrored the habitual performances of the white settlers or tourists who used the hotel, as a space to enact their acquired roles as colonial, a process originally recognized by the Tunisian writer Albert Memmi (1957: 3), who saw in the acts of dispossession of white settlers, a desire to consistently claim their assumed rights based upon what he termed as their 'voyage toward an easier life', grounded upon servants, consumption, and prestige based upon their supposed racial superiority. Naturally, the spatiality of the hotel hosted encounters between locals and workers and settlers. While it is the case that some of these employees have reported on film somewhat wistfully about their time working there see Azevedo's (2007) documentary Hóspedes da Noite - the underlying system of racial segregation was strong. While we could not find sources to discuss these missing voices and there is certainly some fluidity in the interface between antagonistic spaces - the hotel enacted restricted areas for locals, and promoted comfort zones for the white elites.

Up to the mid-1960s, the liberal and progressive Bishop of Beira - Sebastião Soares de Resende - who paradoxically blessed the Grande Hotel in 1955, just days before its opening - was one of the few voices contesting the colonial oppression. Through the newspaper Noticias de Moçambique, which he directed, he often criticised the colonial authorities. His pastoral visits showed him the realities of forced labour, forced cultivation and recurring famines, and one of his famous pastoral letters focused on forced labour and rice cultivation (Morier-Genoud, 2011). He also anticipated the problems the hotel would face, as he wrote in his diary 'It is indeed grandiose and represents a great effort by the Mozambique Company but it was made by mistake' (Resende, 1955). 
At the same time, the hotel was key to the dispensation of amnesia, which allowed, at least momentarily, settlers to consume European modes of living and elide the foundational violence that such comfort was relied upon. As an example of these 'dream topographies' -and the kind of fantasies needed to support and distract the colonial settler which assuaged their anxieties around their role in the occupation, the discussion in Notícias da Beira (1958, 25 January: 6) revolved around a fashion show at the hotel, which focused on how fashionable the drapée was and how Guy Laroche, Jean Dessés and Dior were using new woollen fabrics in Europe. Two weeks later the latest fashion of Paris was presented by a delegation of the so called Comité Français de l'Élégance using Misses France, Finland, Sweden and Paris as models. A reception cocktail was served in the Hotel while the passerelle took place in the Cine-Theatre São Jorge (Notícias da Beira, 1958, 8 February: 1). With a particular focus on the body, on beauty and inevitable intersections with whiteness, these events camouflaged the violent exploitation of the indigenous peoples throughout the colony. By maintaining connections to the Metropole, superficial choreographies in the hairdresser, the swimming pool and in fashion shows, became rituals that empowered the settlers to express and conceal their domination in the same moment As ticketed events, which took place behind closed doors, in air conditioned salons, these enactments were the inverse image of the innumerable sites of exploitation throughout the colony.

Lídia Jorge, in her novel Costa dos Murmúrios (1988), which plays out in the fictional Stella Maris Hotel, has stressed how the elision of violence was largely a result of a dissimulation process we have identified in these practices. She used the fictional hotel to symbolize the crumbling Portuguese Empire in Africa, and as a means to excavate the tensions between nostalgia and collective guilt surrounding Portugal's colonial war in Mozambique (19641975). As we witness the relationship of the two principle characters breaking up, we hear how the hotel 'sank in silence' (Jorge, 1995: 39):

'(...) Whispers of a golden colonial time came to dock there, and consequently people still talked about how the antique bathtubs sat on the floor on top of claw feet. At that time the blacks still could not, or did not want to, meet the white settlers on the same sidewalk. They never turned their backs when they spoke, bowing as they retreated through the doors - if they entered the houses'.

In an interview, which seems to emphasis her own reflection on the kind of colonial unknowing that shaped her experience of Beira, Jorge claimed she '... was deeply disturbed to realised that there was an extreme violence, huge massacres, and, at the same time, an extraordinary appearance of peace. I. . lived a moment of extreme dissimulation, a dissimulation so well done, so well done!' (Letria and Serrano, 1988: 11). This condition was elaborated further, by also enabling their quest to construct their identities as colonial setters and perform accordingly. Up to the 1960s, rigorously enforced laws in Beira banned Africans from 'white' restaurants, theatres, and bathrooms, or simply from being in the city after dark without a pass. These strictures mirrored the same system deployed in South Africa under apartheid (Isaacman and Isaacman, 1983:58). The Mozambican writer Mia Couto (1994: 276) recalls that: 'Whites from Beira were profoundly racist. When I left Beira to Lourenço Marques, in 1971, it seemed I was in a different country, since in Beira was almost Apartheid in certain things'. The only indigenous people permitted to be in the hotel were employees, and all of those working 'front of house', were dressed in elaborate uniforms.

The intensity of these activities certainly peaked in the late 1950s and early 1960s, and an examination of the annual reports and accounts of the Society Tourism Mozambique from 
1956 to 1959 shows that the hotel was profitable, until a point when due to declining guests, the CM mothballed most of the hotel's operations, and stopped taking guests (CM, 1963). Though the archive is incomplete, we can identify a fall in annual guests from 42,668 in 1958 to 31,454 in 1959 to 25,778 in 1960 . On several days in the 1960 s, the colossal hotel had only 4-8 guests (7-8 November 1960; 6-7 February and 24-26 July 1962). The decline was blamed on the poor state of the roads, especially those connecting Beira with Southern Rhodesia (STM, 1956-1959). But the downward trajectory taken by the hotel inevitably responded to political instability in the very region upon which it had based its prosperity, together with dramatic changes to the prospect of the Portuguese empire, which by 1961 had entered into outright war with liberation movements across their African empire. There was an unsuccessful attempt at divesting, which led to a rental contract, but no sale materialised. With the cessation of the rental contract, the administration board decided to close the hotel on 28 February of 1963 (CM, 1963).

Despite the closure, the Grande Hotel remained an important set piece in the colonial imagination, especially when the critical necessity to dissimulate the crisis of the colonial enterprise was deemed necessary (see Diário da Beira, 1971, 9 May: 3). The swimming pool remained open and was used right up to independence as a training ground for the colony's international swim-team. In the years following the hotel's closure, the Overseas Tourist Year-Book had kept advertising it. The 1967 edition retained the standard photo of the hotel with the caption: 'One of the most up-to-date hotels at Beira showing the continuous progress being made in tourism in Mozambique'. The minutes of the CM administration board, the annual reports of the CM and various documents from the Society for Tourism of Mozambique (STM, 1958, 1967), refer obliquely to the war and convey a false hope that the GH could one day open.

Our last look at the hotel revolves around what might be interpreted as a kind of endof-empire party. In 1969, the wedding of Isabel Jardim, daughter of Jorge Jardim, a key figure in colonial Mozambique took place in the hotel. This was indisputably the most extravagant event organized. On one level this spectacle was completely at odds with the political situation in Beira which played a central role in the UN Embargo of Rhodesia. Yet on another level, the event exemplifies the central role of hotels that we have proposed as being central to the prosecution of the colonial enterprise, and the ways in which they were as alien, intrusive and as powerful in remaking the basis of social relations in the colony, as the mining complex and the plantation (Crush, 1984).

This political performance was captured in vivid detail by the Anglican priest John Paul (1975: 215-216):

[Jardim] had taken over a vast hotel in the centre of the city for the occasion, which turned out to be not only a glittering social event, but also a diplomatic jamboree and a masterpiece of propaganda. I was fascinated by the whole performance. Jardim had clearly made excellent use of his daughter's wedding to-proclaim to the world the thoroughly relaxed and contented situation that was supposed to exist in Mozambique. He had set out to demonstrate how powerful and confident was the Portuguese presence in Mozambique, and he made me feel how feeble and doomed to failure were my lonely efforts to fight the system on behalf of the people in Niassa. My attempts to get official evil doers brought to justice, or to obtain redress or even trial for those arrested and detained for no crime, could not succeed against the machine here so intimidatingly portrayed.

Newspapers overflowed with news about the banquet and the wedding gifts exhibited in luxurious salons of the hotel. Jardim, who had ambitions to create a white dominated 
independent state on the lines of Rhodesia (1965), stage-managed the wedding to demonstrate the colony's strength. Yet, despite of its glamour, the hotel is revealed as grotesque. As Isabel Jardim puts it '. . .people would eat and then vomit so they could start eating again' (Saint-Maurice, 2007: 22'26'). But the event served to camouflage the state of affairs in the colony. The Grand Hotel, just like the empire, was crumbling.

In December 1972 in The Times (London) another missionary, Adrian Hastings, accused the Portuguese army of the massacre of about 400 people at the village Wiriyamu. These atrocities were part of a war against the people, he later described, '... as whole series of massacres. . . for ghastliness each rivalling that of My Lai' (Hastings, 1973: 1). By the end of 1973, there were 148,000 military in Portuguese Africa, and 50,000 in Mozambique alone. Yet, throughout this process, the hotel was used to stage a series of events and parties, actively dissimulating the realities of the violence that increasingly gripped the colony. Not least of which were a series of Miss Mozambique competitions. (Diário da Beira, 1971, 9 May: 3). One of these women, Iris Maria, was eventually crowned Miss Portugal, and represented the country in the traditional dress of an indigenous African women, shorn of it integrity and recast as an erotic other. The aim of these distractions created a system of denial for the colonial settlers, and the hotel was a key agent in this dissimulation process. This is quite clear in an interview with Isabel Jardim. Her individual memories, seem to articulate the epitome of colonial unknowing: 'For me, Beira was everything, because it was a youth packed with fun, very healthy, very good. I have no negative memories at all' (...) 'We had absolutely no notion that things could go wrong' (Saint-Maurice, 2007). The hotel, in all its material and symbolic dimensions, contributed to the emergence of sweet geographical imaginations in which the city and the colony were projected as pleasant and progressive spaces. Luxury and its spaces are thus revealed as a form of violence.

\section{Conclusion}

Bernard Tschumi (1996: 100) has argued that 'architecture is defined by the actions it witnesses as much as by the enclosure of its walls'. Thus, 'there is no architecture without action, no architecture without events, no architecture without program' (121). We have argued that attention to the intimate spatialities, attributes and conditions expressed at this site - and indeed in other colonial leisure and tourist sites - has revealed them as an integral part of a system of colonial oppression. We developed this insight in two broad ways. First, we deployed a dispersed concept of violence, in which we have recognised it as strategic and mutable process, which moves over and in-between epistemic, embodied, physical and symbolic domains and over heterogeneous zonalities and temporalities. These domains we recognised in the ways the city of Beira was planned, its architecture shaped and represented, and in the recreational and social performances of an essentially racist white settler culture. They imposed orders and hierarchies. Second, our insight into the hotel was animated by drawing upon the praxis at the intersection of geography and architectural studies, which seek out relational and performative qualities of buildings and the uses they are put to. Indeed, it has become clear that by converging a flat ontology of both violence and architecture and explicitly exploring these intersections in the context of the colonial city that the violent attributes of settler spaces and performances can be revealed. We have found that unlike hotels in the metropoles of the West in the early twentieth century which functioned as 'extensions of public space in the form of the lobby or the bar' (McNeill, 2008: 395), the colonial hotel was a racially exclusionary site and keystone institution for the social construction of white-settler identities and subjectivities. The colonial hotel not only insulated colonial society but also offered multiple opportunities to build and 
perform notions of racial superiority, quash moral and ethical dilemmas about settler's role in exploitation, and restore the vitality of settlers stressed by prosecuting the brutalities necessary to maintain the colonial regime. This space of violence built upon the production of distraction and self and public denial. What emerges also strongly from this research is that these dissimulation processes were played both at the scale of the city and colony, and from the colony to the metropolis. These observations demonstrate that the epistemological and geographical gap between colony and metropolis that obscured colonial violence, was central to the construction of white settler space. Jameson (2003: 700) stresses that '...imperialism masks and conceals the nature of its system', as a 'spatial disjunction' warranting the inability to grasp the way the system functioned as a whole. The 'simultaneous necessity and impossibility of grasping the structural connections between the daily life of the metropolis and the absent space of the colony' (Britzolakis, 2007: 457) to which Jameson refers, suggests the resilience of colonies was ensured in part only as long as violence was obscured and dissimulated (Driver and Gilbert, 1999). Performances, dinner dances, receptions, commemorations, fashion shows and so on, all played a key role in news that circulated in regional, national and even international media operating as an experience for the settlers. Within the Portuguese empire, the hotel, in all its material and symbolic dimensions, contributed to the emergence of an imaginary in which the city and the colony were projected as pleasant and progressive spaces. We have argued in addition that the apparently non-violent characteristics of these spaces, the performances and practise they staged, need to be carefully unmasked to reveal their role in producing oppression in the colonial city and the racist state. As noted by Hom (2012: 30) '...colonial tourism disavowed the violent, insidious nature of imperialism, covering it over with a patina of leisure and making palatable, even pleasurable, the destruction of indigenous social fabrics and the unchecked demolition of economic, political, and social systems'. The organisation of violence, and its prosecution, have historically been maintained through quotidian practices or the state sanctioned provision of pleasure and rewards. Moreover, as observed by Smirl (2015), the legacies of the formations of the colonial hotel remain in place elsewhere and continue to shape both the meaning of hotels and the manner in which they shape westerners perception of themselves and the countries they visit across the post-colonial world. In terms of key contribution to research on the intersectionality of violence and the architecture, these observations are important, as we have suggested that we must consider these junctures not only when a building is destroyed by war or involved in strategic acts of dispossession, but also when more subtle and disperse processes of violence are at play. Often the violent attributes of architecture are hidden to some degree in plain sight, sometimes in apparently the most frivolous moments and spaces. Violence is a social and spatial process that goes beyond sudden harm and destruction but is capable of being expressed more slowly over time and space and dissimulated in seemingly pleasurable and benign practices. In spite of its charm and luxury, the hotel as a capitalist, colonial and political project encapsulated the most violent inequalities of the colony. A no-zone for locals and a comfort zone for the white elites, it became a safe ground for businesses and family life. The Hotel, enclaves that we can term 'spaces of disassociation', need to be recaptured along with the more obvious military camp, the mining complex or the plantation, as a key site of colonial violence.

\section{Acknowledgements}

Fieldwork in Mozambique was possible due to the funding from the Portuguese Foundation for Science and Technology (SFRH/BSAB/1430/2014) and the support from the Centre for Geographical Studies, University of Lisbon. The authors are grateful to the four anonymous reviewers 
for their comments and to the editorial support of Kate Derickson. The paper benefited also from the advice from Richard Ballard and Gerry Kearns.

\section{Declaration of conflicting interests}

The author(s) declared no potential conflicts of interest with respect to the research, authorship, and/or publication of this article.

\section{Funding}

The author(s) received no financial support for the research, authorship, and/or publication of this article.

\section{References}

Alexandre V (2017) Contra o Vento. Portugal, o Império e a Maré Anticolonial (1945-1960). Lisbon: Temas \& Debates.

Alsayyad N (ed.) (1992) Forms of Dominance: On the Architecture and Urbanism of the Colonial Enterprise. Aldershot: Avebury Publishers.

Amutabi M (2016) Buildings as Symbols and Metaphors of Colonial Hegemony: Interrogating Colonial Buildings and Architecture in Kenya's Urban Spaces. In Demissie, F (ed.) Colonial Architecture and Urbanism in Africa: Intertwined and Contested Histories. Farnham: Ashgate, pp.325-346.

Anderson P (1962) Portugal and the End of Ultra-Colonialism. New Left Review I(15): 82-102.

Anderson S (2015) Modern Architecture and Its Representation in Colonial Eritrea: An in-Visible Colony, 1890-1941. Farnham: Ashgate.

Andrade CR (1932) Alargamento e embelesamento da cidade da Beira. Arquitectura, Revista de arte e construção, 24, April, pp.134-135.

Aniebo I (1974) The Anonymity of Sacrifice. London: Heinemann.

Arndt G (2016) Settler agnosia in the field: Indigenous action, functional ignorance, and the origins of ethnographic entrapment. American Ethnologist 43(3): 465-474.

Azevedo L (2007) Hóspedes da Noite. Ebano Multimedia.

Bauman Z (1989) Modernity and the. Holocaust. Ithaca: Cornell University Press.

Bigon L (2013) Garden Cities in Colonial Africa: a note on historiography. Planning Perspectives 28(3): 477-485.

Britzolakis C (2007) 'This way to the exhibition': genealogies of urban spectacle in Jean Rhys's interwar fiction. Textual Practice 21(3): 457-482.

Bufacchi V (2017) 'Colonialism, Injustice, and Arbitrariness'. Journal of Social Philosophy 48(2): 197-211.

Byrd J (n.d) "Silence Will Fall: The Cultural Politics of Colonial Agnosia." Unpublished manuscript, last modified (2014)

Césaire A (1950) Discourse on Colonialism. New York: Monthly Review Press.

CM (1942) Various correspondence of the Companhia de Moçambique. Historical Overseas Archive, Lisbon [Process 53194, OP00808, 7-1-3].

CM (1943) Various correspondence of the Companhia de Moçambique. Historical Overseas Archive, Lisbon [Process 53194, OP00808, 7-1-3].

CM (1959) Inventory. 31st December. National Archive of Torre do Tombo [Folder 288].

CM (1963) Report and Accounts of the Companhia de Moçambique. Mozambique National Archive, Maputo.

Coetzee JM (1988) White Writing: On the Culture of Letters in South Africa. New Haven, Connecticut/ London: Yale University Press.

Couto M (1994) Mia Couto. In Chabal, P (ed.) Vozes Moçambicanas. Literatura e Nacionalidade. Vega: Lisbon. 
Craggs R (2012) Towards a political geography of hotels: Southern Rhodesia, 1958-1962. Political Geography 31 (4): 215-224.

Crush J (1984) Scripting the compound: power and space in the South African mining industry. Environment and Planning D: Society and Space 12(3): 301-324.

Dadié B (1984) Climbié. London: Heinemann.

De Leeuw S (2016) Tender grounds: Intimate visceral violence and British Columbia's colonial geographies. Political Geography 52: 14-23.

Dean E (1979) In the Primitive Sun The Age December 3, p.18.

Demissie F (2007) Imperial legacies and postcolonial predicaments. African Identities 5(2): 155-165.

Denby E (1998) Grand Hotels, Reality and Illusion: an Architectural and Social History. London: Reaktion.

Driver F and Gilbert D (eds) (1999) Imperial Cities: Landscape, Display and Identity. Manchester: Manchester University Press.

Enloe C (2000) Maneuvers. The International Politics of Militarising Women's Lives. Oakland: University of California Press.

Fanon F (1963) The Wretched of the Earth. Harmondsworth: Penguin.

Fernandes J (2002) Geração Africana-Arquitecturas e Cidades em Angola e Moçambique, 1925-1975, Livros do Horizonte: Lisboa.

Foster J (2008) Washed with Sun: landscape and the Making of White South Africa. Pittsburgh: University of Pittsburgh Press.

Fregonese S and Ramadan A (2015) Hotel Geopolitics: A Research Agenda. Geopolitics 20: 793-813.

Goh D (2010) Capital and the transfiguring monumentality of raffles hotel. Mobilities 5 (2): 177-195.

Graham S (2010) Cities under Siege: The New Military Urbanism. London: Verso.

Hastings A (1973) Portuguese Massacre Reported by Priests. The Times, 10 July, pp.1 \& 5.

Henderson P (2017) Imagoed communities: the psychosocial space of settler colonialism. Settler Colonial Studies 17(1): 40-56.

Hom S (2012) Empires of tourism: travel and rhetoric in Italian colonial Libya and Albania, 19111943. Journal of Tourism History 4 (3): 281-300.

Hughes DM (2010) Whiteness in Zimbabwe: Race, landscape, and the problem of belonging. New York: Palgrave MacMillan.

Isaacman A and Isaacman B (1983) Mozambique. From Colonialism to Revolution, 1900 to 1982. Westview Press: Colorado.

Jacobs J, Cairns S and Strebel I (2012) Doing building work: Methods at the interface of geography and architecture. Geographical Research 50(2): 126-140.

Jameson F (2003) The End of Temporality. Critical Inquiry 29(4): 695-718.

Jorge L (1995) The Murmuring Coast. Minneapolis: University of Minnesota Press.

Katz M (1999) The Hotel Kracauer. Differences: A Journal of Feminist Cultural Studies 11(2): 134-152.

Kenzari B (2011) Architecture and Violence. Barcelona: Actar.

King A (2007) Colonial Urban Development. Culture, Social Power and Environment. London: Routledge.

Kracauer S (1995) The Mass Ornament: Weimar Essays. Cambridge: Harvard University Press.

Kraftl P and Adey P (2008) Architecture/affect/inhabitation: geographies of being-in buildings. Annals of the Association of American Geographers 98 (1): 213-231.

Kusno A (2000) Behind the Postcolonial: Architecture, Urban Space, and Political Cultures in Indonesia. New York: Routledge.

Leatherbarrow D (2009) Architecture Oriented Otherwise. New York: Princeton Architectural Press,

Lees L (2001) 'Towards A Critical Geography of Architecture'. Cultural Geographies 8(1): 51-86.

Legg S (2007) Spaces of Colonialism. Delhi's Urban Governmentalities. Malden: Blackwell.

Lester A (1998) Reformulating identities: British settlers in nineteenth century South Africa. Transactions of the Institute of British Geographers 23(4): 515-531.

Letria J and Serrano M (1988) 'A escrita é mesmo a minha vida'. O Diário - Fim de Semana, 5 Março 11: 12. interview with Lídia Jorge. 
Linehan D and Sarmento J (2011) Spacing Forgetting: The Birth of the Museum at Fort Jesus, Mombasa, and the Legacies of the Colonization of Memory in Kenya. In Cultural Memories (pp. 305-325). Springer, Dordrecht.

Lord G (1990) The Sewer of Africa, The Spectator May 5th, page 19

Lorne C (2017) Spatial agency and practising architecture beyond buildings. Social \& Cultural Geography 18 (2): 268-287.

Marston S, Jones J and Woodward K (2005) 'Geography without scale'. Transactions of the Institute of British Geographers 30 (4): 416-432.

McNeill D (2008) The hotel and the city. Progress in Human Geography 32(3): 383-398.

Memmi A (1957) Portrait du colonisé. Esprit (1940-), 250(5): 790-810.

Mhango M (2015) Africa must get rid of colonial debris. In Mawere M and Mubaya TR (Eds) Colonial Heritage, Memory and Sustainability in Africa: Challenges, Opportunities and Prospects. Bamenda, Cameroon: Langaa RPCIG, pp.87-104.

Milheiro A (2012) Nos Trópicos Sem Le Corbusier. Arquitectura Luso-Africana No Estado Novo. Relógio D'Água: Lisboa

Minca C and Ong C (2016) The power of space: The biopolitics of custody and care at the Lloyd Hotel, Amsterdam. Political Geography 52: 34-46.

Morier-Genoud E (2011) Dom Sebastião Soares de Resende. In Gates H and Akyeampong E (Eds). Dictionary of African Biography. Oxford University Press.

Morrison, K. (2016) Sarajevo's Holiday Inn on the Frontline of Politics and War. UK: Palgrave Macmillan.

Mudimbe V (1988) The Invention of Africa. Indiana University Press: Bloomington.

Neil-Tomlinson J (1987) The Mozambique Chartered Company, 1892-1910. Unpublished PhD, University of London: London.

Newitt MDD (1995) A History of Mozambique. Bloomington: Indiana University Press.

Nixon R (2011) Slow Violence and the Environmentalism of the Poor. Cambridge: Harvard University Press.

Paul J (1975) Mozambique: Memoirs of a Revolution. Penguin Books: Middlesex.

Peleggi M (2005) Consuming colonial nostalgia: The monumentalisation of historic hotels in urban South-East Asia. Asia Pacific Viewpoint 46(3): 255-265.

Peleggi M (2012) The Social and Material Life of Colonial Hotels: Comfort Zones as Contact Zones in British Colombo and Singapore, ca. 1870-1930. Journal of Social History 46(1): 124-153.

Penvenne JM (1995) African workers and colonial racism: Mozambican strategies and struggles in Lourenço Marques, 1877-1962. James Currey: London

Pulido L (2000) 'Rethinking Environmental Racism: White Privilege and Urban Development in Southern California'. Annals of the Association of American Geographers 90(1): 12-40.

Resende S (1955) Personal diaries - 1953-1957. Library of the Oporto Arts Faculty, Porto.

Saint-Maurice A (2007) Grande Hotel. RTP

Sidaway J and Power M (2005) 'The tears of Portugal': empire, identity, 'race', and destiny in Portuguese geopolitical narratives. Environment and Planning D: Society and Space 23(4): 527-554.

Silva, CN (Ed) (2016) Urban Planning in Lusophone African Countries. Routledge: London.

Smirl L (2015) Spaces of Aid: how Cars, Compounds and Hotels Shape Humanitarianism. London: Zed Books.

Springer S (2014) Human geography without hierarchy. Progress in Human Geography 38(3): 402-419.

STM (1956-1959) Relatório e Contas da Sociedade de Turismo de Moçambique [Report and Accounts of the Mozambique Tourism Society]. Imprensa Portugal-Brasil: Amadora.

STM (1958) Correspondence from the Society for Tourism of Mozambique to the Administration of the Companhia de Moçambique. National Archive of Torre do Tombo [Box 289, stack289, folder 495-1].

STM (1967) Anuário Turístico de Moçambique [Annual Tourism Report of Mozambique], 2, 1966/67, Porto Municipal Library.

Stoops L (2010) Grande Hotel. Serendipity Films: Brussels.

Tostões A (2013) (ed.) Modern Architecture in Africa: Angola and Mozambique. Lisbon: FCT. 
Tschumi B (1996) Architecture and Disjunction. MIT: Cambridge, Massachusetts.

Vasudevan A (2011) Dramaturgies of Dissent: The Spatial Politics of Squatting in Berlin, 1968. Social and Cultural Geography 12(3): 283-303.

João Sarmento holds a PhD from the University College Cork, Ireland. He joined the Geography Department at the University of Minho, Portugal, in 1999, where he is an Assistant Professor with habilitation. He is also a Researcher at the Communication and Society Research Centre, University of Minho, Portugal. His research and publications are in the fields of Cultural Geography, Postcolonial Studies, Tourism Geography and Geographical Thought, focusing especially on Lusophone Africa, the Middle East and Central Asia.

Dr Denis Linehan is a graduate of the University of Nottingham. He joined the Department of Geography at University College Cork, in 1999, having previously worked at the University of Swansea and the University of Lancaster. He teaches across a broad range of graduate and undergraduate modules in the University, in areas concerned with the contemporary and historical conditions of urban life. Currently he convenes the MA Geography: Cities, Space \& Culture and an active PhD research group in human geography. His research has been published in Transactions of the Institute of British Geographers, Journal of Historical Geography, Cultural Geographies, Social and Cultural Geography, Irish Geography and Environment and Planning D: Society and Space, amongst others. 